\title{
How I do it: microsurgical clipping of carotid-ophthalmic aneurysms through minipterional approach with extradural resection of the anterior clinoid process
}

\author{
Albert A. Sufianov ${ }^{1,2}$, Egor S. Markin', Ivan S. Sheliagin ${ }^{1,2, 凶}$, Rinat A. Sufianov ${ }^{2,3}$ \\ ${ }^{\prime}$ Federal Centre of Neurosurgery, Tyumen \\ 5, 4th km Chervishevskogo tract, Tyumen, 625032, Russia \\ ${ }^{2}$ Sechenov First Moscow State Medical University (Sechenov University) \\ 8/2, Trubetskaya str., Moscow, 119991, Russia \\ ${ }^{3}$ Burdenko Neurosurgical Institute \\ 16, 4th Tverskaya-Yamskaya str., Moscow, 125047, Russia
}

\begin{abstract}
Background. In modern neurosurgery, preference is given to less invasive procedures. A classic example is switching from standard surgical approaches to keyhole approaches, in particular transition from pterional to minipterional approach.

In turn, addition of extradural resection of the anterior clinoid process to the minipterional approach significantly expands the range of its indications.

Method. The paper analyses the stages and main features of microsurgical clipping of carotid-ophthalmic aneurysms through the minipterional approach with extradural anterior clinoidectomy in patients operated in the Federal Centre of Neurosurgery (Tyumen, Russia) by professor Sufianov.

Conclusion. The technique described in this research is a safe surgical approach, which demonstrates the efficacy of adding some skull base surgery elements to keyhole approaches. This type of craniotomy could become a method of choice for many neurosurgical conditions.
\end{abstract}

Keywords: vascular neurosurgery; skull base surgery; keyhole surgery; anterior clinoid process; internal carotid artery; aneurysm

MeSH terms:

ANEURYSM - DIAGNOSIS

ANEURYSM - SURGERY

CAROTID ARTERY, INTERNAL - SURGERY

CAROTID ARTERY DISEASES - DIAGNOSIS

CAROTID ARTERY DISEASES - SURGERY

SPHENOID BONE - SURGERY

MICROSURGERY - METHODS

For citation: Sufianov A.A., Markin E.S., Sheliagin I.S., Sufianov R.A. How I do it: microsurgical clipping of carotid-ophthalmic aneurysms through minipterional approach with extradural resection of the anterior clinoid process. Sechenov Medical Journal. 2021; 12(4): 51-63. https://doi.org/10.47093/2218-7332.2021.12.4.51-63

CONTACT INFORMATION:

Ivan S. Sheliagin, neurosurgeon, Federal Center of Neurosurgery; Postgraduate at the Department of Operative Surgery and Topographic Anatomy, Sechenov First Moscow State Medical University (Sechenov University).

Address: 5, 4th km Chervishevskogo tract, Tyumen, 625032, Russia

Tel.: +7 (919) 9545381

E-mail: sheliaginivan@outlook.com

Conflict of interests. The authors declare that there is no conflict of interests.

Financial support. The study was not sponsored (own resources).

Received: 16.07 .2021

Accepted: 22.08 .2021

Date of publication: 29.11 .2021 


\title{
Как я это делаю: микрохирургическое клипирование каротидно-офтальмических аневризм через мини-птериональный доступ с экстрадуральной резекцией переднего наклоненного отростка
}

\author{
А.А. Суфианов ${ }^{1,2}$, Е.С. Маркин ${ }^{1}$, И.С. Шелягин ${ }^{1,2, 凶}$, Р.А. Суфианов ${ }^{2,3}$ \\ ${ }^{I}$ ФГБУ «Федеральный иентр нейрохирургии» Минздрава России \\ 4-й км Червишевского тракта, 5, Тюмень, 625032, Россия \\ ${ }^{2}$ ФГАОУ ВО «Первый Московский государственный медицинский университет \\ им. И.М. Сеченова» Минздрава России (Сеченовский Университет) \\ ул. Трубеикая, д. 8, стр. 2, г. Москва, 119991, Россия \\ ${ }^{3}$ ФГАУ «Национальный медичинский исследовательский центр нейрохирургии \\ имени академика Н.Н. Бурденко» Минздрава России \\ ул. 4-я Тверская-Ямская, д. 16, г. Москва, 125047, Россия
}

\section{Аннотация}

Актуальность. В современной нейрохирургии предпочтение отдается снижению инвазивности проводимых процедур. Классическим примером является переход от стандартных операционных доступов к keyhole-доступам, в частности переход от птерионального доступа к мини-птериональному. В свою очередь, добавление к мини-птериональному доступу экстрадуральной резекции переднего наклоненного отростка значительно расширяет спектр показаний к его выполнению.

Методы. Представлены этапы и основные особенности микрохирургического клипирования каротидно-офтальмологических аневризм с применением мини-птерионального доступа с экстрадуральной передней клиноидэктомией на основании выполнения данных оперативных вмешательств в условиях Федерального центра нейрохирургии (Россия, Тюмень) профессором А.А. Суфриановым.

Заключение. Мини-птериональный доступ с экстрадуральной резекцией переднего наклоненного отростка является безопасным операционным доступом, служащим одним из примеров добавления к keyhole-доступам элементов хирургии основания черепа. Данный тип краниотомии может стать методом выбора в лечении широкого спектра нейрохирургической патологии.

Ключевые слова: сосудистая нейрохирургия; хирургия основания черепа; keyhole-доступ; передний наклоненный отросток; внутренняя сонная артерия; аневризма

Рубрики MeSH:

АНЕВРИЗМА - ДИАГНОСТИКА

АНЕВРИЗМА - ХИРУРГИЯ

СОННАЯ АРТЕРИЯ ВНУТРЕННЯЯ - ХИРУРГИЯ

СОННОЙ АРТЕРИИ БОЛЕЗНИ - ДИАГНОСТИКА

СОННОЙ АРТЕРИИ БОЛЕЗНИ - ХИРУРГИЯ

КЛИНОВИДНАЯ КОСТЬ - ХИРУРГИЯ

МИКРОХИРУРГИЯ - МЕТОДЫ

Для цитирования: Суфианов А.А., Маркин Е.С., Шелягин И.С., Суфианов Р.А. Как я это делаю: микрохирургическое клипирование каротидно-офттальмических аневризм через мини-птериональный доступ с экстрадуральной резекцией переднего наклоненного отростка. Сеченовский вестник. 2021; 12(4): 51-63. https://doi.org/10.47093/22187332.2021.12.4.51-63

\section{КОНТАКТНАЯ ИНФОРМАЦИЯ:}

Шелягин Иван Сергеевич, нейрохирург ФГБУ «Федеральный центр нейрохирургии» Минздрава России; соискатель кафедры оперативной хирургии и топографической анатомии ФГАОУ ВО «Первый МГМУ им. И.М. Сеченова» Минздрава России (Сеченовский Университет).

Адрес: 4-й км Червишевского тракта, 5, Тюмень, 625032, Россия

Тел.: +7 (919) 9545381

E-mail: sheliaginivan@outlook.com 
Конфликт интересов. Авторы заявляют об отсутствии конфликта интересов.

Финансирование. Исследование не имело спонсорской поддержки (собственные ресурсы).

Поступила: 16.07.2021

Принята: 22.08.2021

Дата печати: 29.11.2021

\section{List of abbreviation}

ACP - anterior clinoid process

ICA - internal carotid artery

The conventional pterional approach is the "gold standard" in the surgical treatment of most neurosurgical pathologies $[1,2]$. However, in modern neurosurgery, there has been a tendency to develop minimally invasive procedures. A classic example is the transition from standard surgical approaches to keyhole approaches, 3-5 $\mathrm{cm}$ in size, and in particular, the transition from pterional approach to minipterional approach [3-5].

Along with a wide range of advantages of these approaches, there are several limitations. The

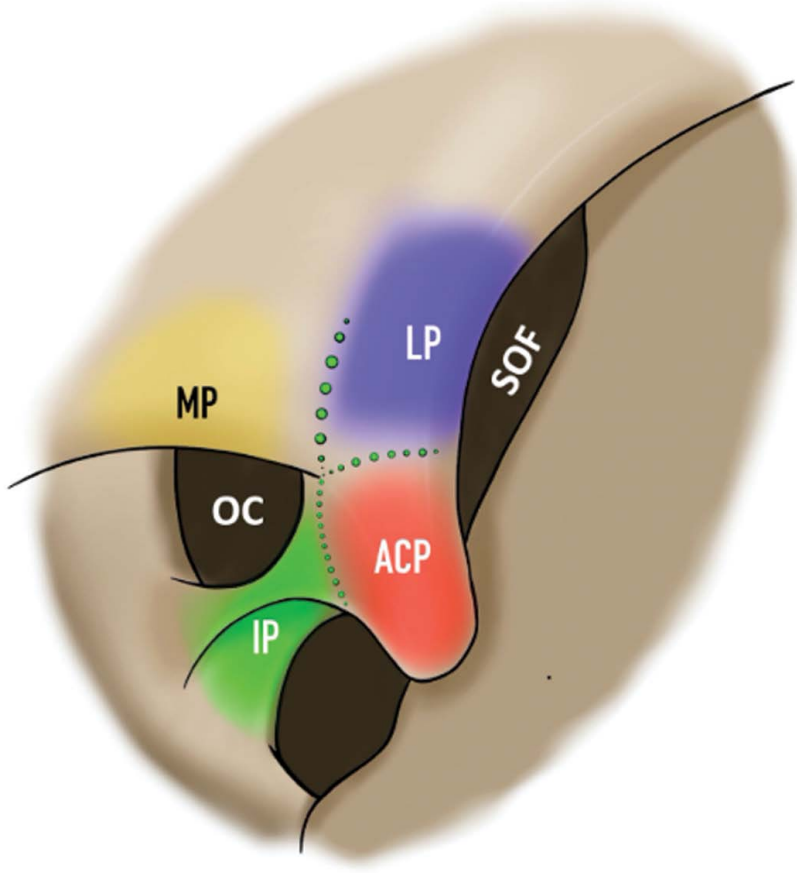

FIG. 1. Schematic representation of the pillars of the anterior clinoid process.

РИС. 1. Схематичное изображение ножек переднего наклоненного отростка.

Note: ACP - anterior clinoid process; IP - inferior pillar (optic strut); LP lateral pillar (sphenoid wing); OC - optic canal; MP - medial pillar (roof of the optic canal); SOF - superior orbital fissure.

Примечание: ACP (anterior clinoid process) - передний наклоненный отросток; IP (inferior pillar) [optic strut] - нижняя ножка [зрительная перегородка]; LP (lateral pillar) [sphenoid wing] - латеральная ножка [крыло клиновидной кости]; OC (optic canal) - канал зрительного нерва; MP (medial pillar) [roof of the optic canal] - медиальная ножка [крыша канала зрительного нерва]; SOF (superior orbital fissure) верхняя глазничная щель.

combination of keyhole approaches with elements of skull base surgery can significantly expand the range of indications [6].

Using the combination of minipterional approach (keyhole approach) with extradural resection of the anterior clinoid process (ACP) - an element of skull base surgery - we can significantly expand the range of indications for this approach. The main indications are: paraclinoid aneurysms of the internal carotid artery in patients having contraindications for endovascular treatment; small lesions of the sella turcica, the area of the sphenoid bone wings, and the anterior clinoid process; optic nerve gliomas; pathologies requiring decompression of the optic canal [7-10].

The article describes the technique and features of performing the minipterional approach with extradural clinoidectomy demonstrated by the case of the carotidophthalmic aneurysm clipping.

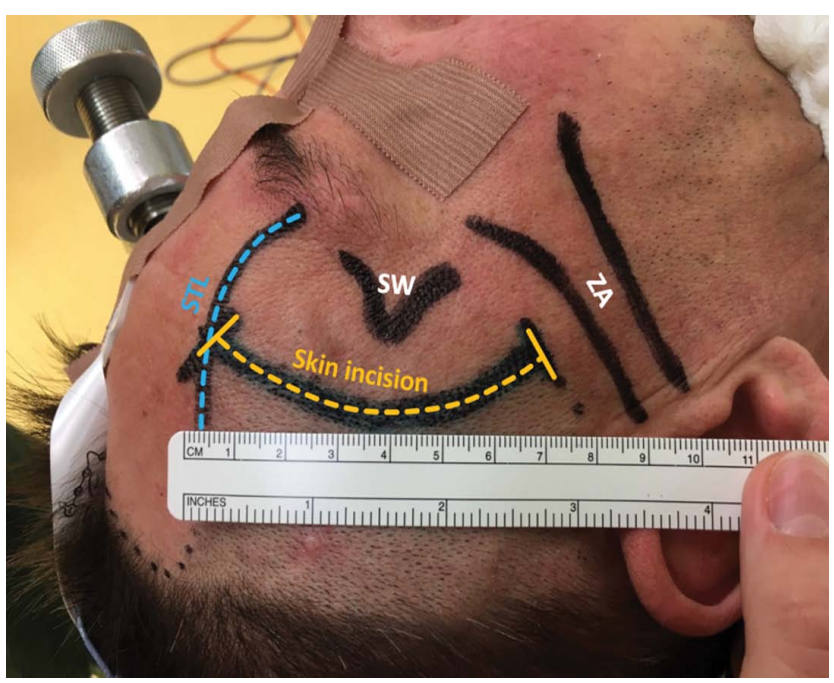

FIG. 2. Patient positioning, skin incision planning. An arcuate skin incision is made just behind the hairline, $1 \mathrm{~cm}$ above the zygomatic bone.

РИС. 2. Планирование кожного разреза. Дугообразный разрез кожи делается сразу за линией роста волос, на 1 см выше скуловой кости.

Note: STL - superior temporal line; SW - sphenoid wing; ZA - zygomatic arch.

Примечание: STL (superior temporal line) - верхняя височная линия; SW (sphenoid wing) - крыло клиновидной кости; ZA (zygomatic arch) скуловая дуга. 


\section{ANATOMICAL FEATURES}

The superior orbital fissure is bounded laterally by a fold formed by the dura covering the frontal and temporal lobes, called the meningo-orbital band, which attaches the temporal lobe to the wall of the cavernous sinus and the ACP.

Anatomically, the ACP is attached to the wing of the sphenoid bone by three bony structures (pillars) (Fig. 1):

(1) a lateral pillar, which is formed by a wedgeshaped ridge and is bounded from below by the superior orbital fissure;

(2) the medial pillar that forms the roof of the optic canal;

(3) the inferior pillar (or optic strut), which separates the supraclinoid portion of the internal carotid artery (ICA) inferolaterally from the superior medial optic nerve.

A

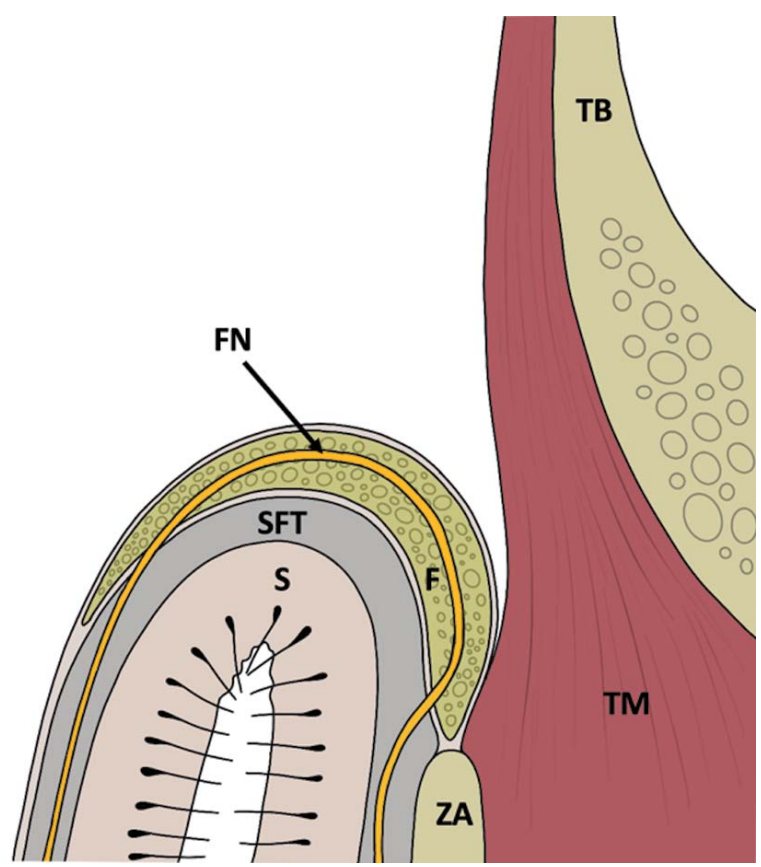

\section{SURGICAL TECHNIQUE}

\section{Patient positioning and skin incision}

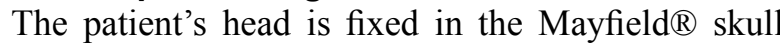
clamp in the same way as described for the classic pterional approach. A 5-7 cm curvilinear skin incision along the hairline is usually sufficient to expose an area of the bone for the craniotomy (Fig. 2).

To prevent intraoperative damage to the branches of the facial nerve, dissection of interaponeurotic fatty tissue is performed along the border between the latter and the temporal muscle. The temporalis muscle can then be safely dissected downwards without the risk of damaging the branches of the facial nerve that remain in the adipose tissue (Fig. 3a, 3b).

The temporalis muscle is dissected using an interfascial technique and retracted downward until the superior orbital margin and pterion are exposed.

B

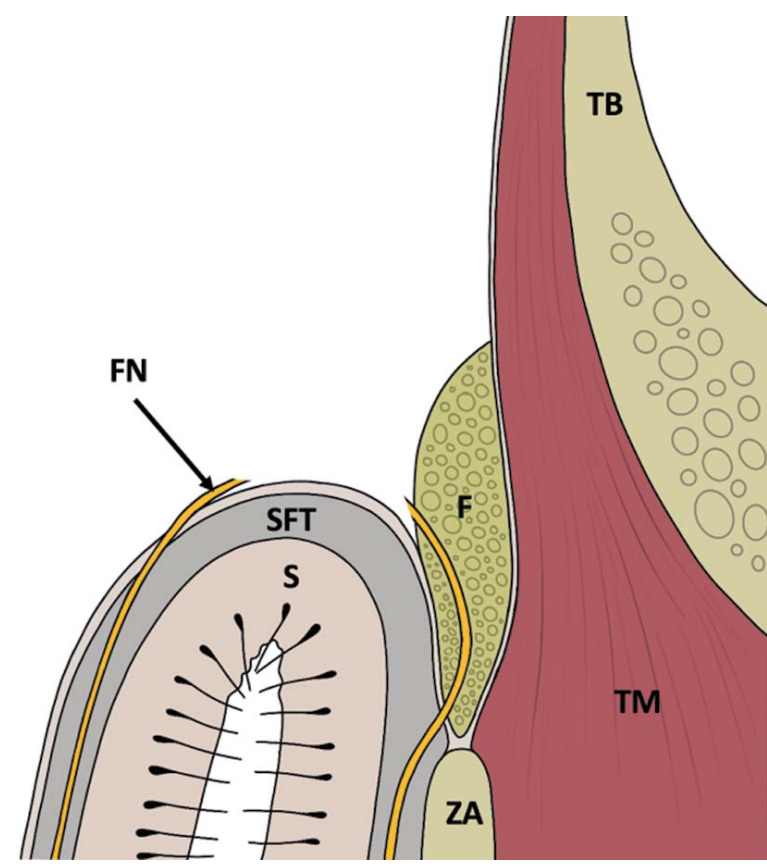

FIG. 3. Schematic representation of the dissection of interaponeurotic fatty tissue along the border with the temporal muscle to prevent damaging the branches of the facial nerve.

A. The aponeurotic skin flap is separated along the border between the interaponeurotic fatty tissue and the temporalis muscle. The facial nerve is intact.

B. The aponeurotic skin flap is separated along the border with the interaponeurotic fatty tissue, and the branches of the facial nerve are crossed.

РИС. 3. Схематичное изображение диссекции жирового комка по границе с височной мышцей для предотвращения повреждения веток лицевого нерва.

А. Кожно-апоневротический лоскут отделен по границе между межапоневротической жировой клетчаткой и височной мышцей, лицевой нерв цел.

В. Кожно-апоневротический лоскут отделен по границе с межапоневротической жировой клетчаткой, ветки лицевого нерва пересечены.

Note: $\mathrm{F}$ - interaponeurotic fatty tissue; $\mathrm{FN}$ - facial nerve; $\mathrm{S}$ - skin; SFT - subcutaneous fatty tissue; TB - temporal bone; TM - temporal muscle; ZA zygomatic arch.

Примечание: F (fat) - межапоневротическая жировая клетчатка; FN (facial nerve) - лицевой нерв; S (skin) - кожа; SFT (subcutaneous fatty tissue) - подкожная жировая клетчатка; TB (temporal bone) - височная кость; TM (temporal muscle) - височная мышцца; ZA (zygomatic arch) скуловая дуга. 


\section{Craniotomy}

Classic pterional craniotomy involves approaching from within the frontal, parietal, temporal, and sphenoid bones, and its superior border extends beyond the superior temporal line. Minipterional craniotomy is a $3 \times 5 \mathrm{~cm}$ craniotomy, and its upper border does not go beyond the superior temporal line (Fig. 4).

A $3 \times 5 \mathrm{~cm}$ craniotomy is performed below the superior temporal line (minipterional craniotomy) (Fig. 5).

The dura mater, covering the temporal and frontal lobes, and the lesser wing of the sphenoid bone are exposed.

Then, using a cutting burr, the lesser wing of the sphenoid bone is resected to the outer edge of the superior orbital fissure. This allows the lateral pedicle of the ACP to be removed.

\section{Extradural part of approach}

The meningo-orbital band is coagulated and dissected. In this case, the periosteal layer of the dura mater is dissected above the lateral wall of the cavernous sinus. This allows the surgeon to get into the layer between the dura mater layers and, if necessary, perform the "peeling" of the cavernous sinus wall. At the same time, it is possible to mobilize the dura mater of the temporal lobe outwards, and completely expose the ACP.

\section{Extradural anterior clinoidectomy}

At this stage, only the medial and inferior pedicles are still holding the ACP in place, as the lateral pedicle was removed during the resection of the lesser wing of the sphenoid bone and part of the roof of the superior orbital fissure.

Removal of the optic septum and medial stem of the ACP is most safely performed using specialized bone clippers (Muranaka, Japan) (Fig. 6A, 6B). After resection of all bone pillars, the ACP becomes mobile and is fixed mainly due to the petroclinoidal and interclinoidal ligaments. A complete dissection of the ACP is performed by sharply dissecting these ligaments with microscissors or a specialized sickle-shaped microdissector (Feather, Japan) (Fig. 6C, 6D).

Then, the ACP is removed and the paraclinoid portion of the internal carotid artery is exposed (Fig. 7A-C).

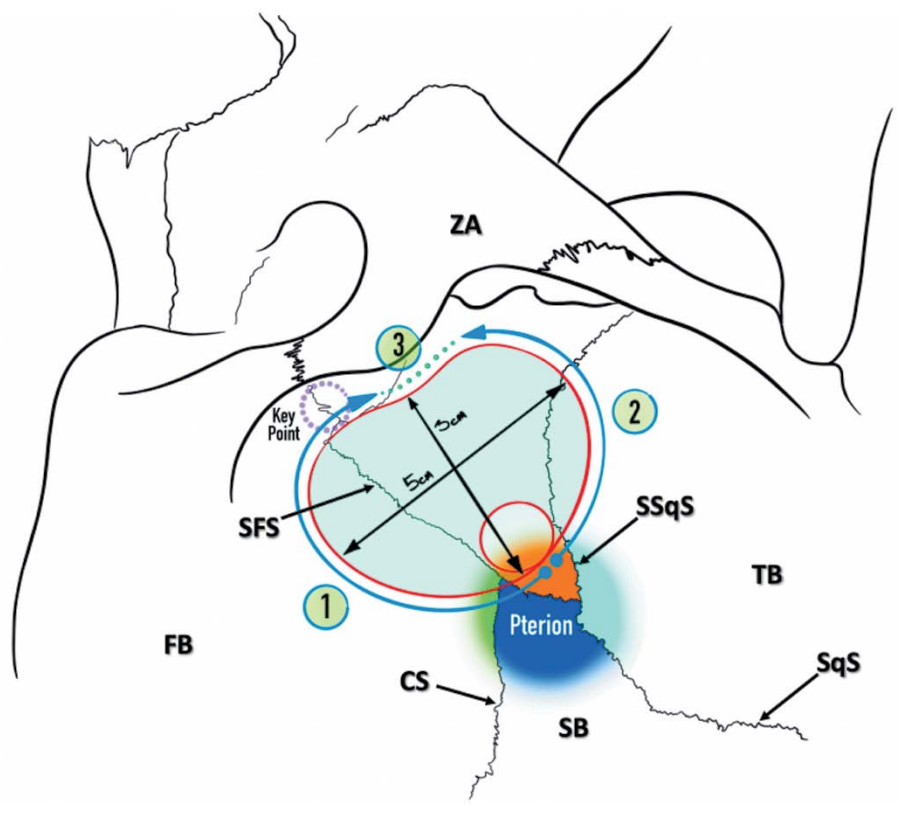

FIG. 4. Schematic representation of the stages of minipterional craniotomy.

(1) The first stage of craniotomy is performed in an arcuate manner from the burr hole along the superior temporal line to the large wing of the sphenoid bone;

(2) The second stage of the craniotomy is performed in an arcuate manner from the milling hole to the large wing of the sphenoid bone;

(3) Resection of the outer plate of the greater wing of the sphenoid bone with a cutting bur.

РИС. 4. Схематическое изображение этапов выполнения мини-птериональной краниотомии.

(1) Первый этап краниотомии выполняется дугообразно от фрезевого отверстия вдоль верхней височной линии к большому крылу клиновидной кости;

(2) Второй этап краниотомии выполняется дугообразно от фрезевого отверстия к большому крылу клиновидной кости;

(3) Резекция наружной пластинки большого крыла клиновидной кости режущим бором.

Note: TB - temporal bone; SB - sphenoid bone; FB - frontal bone; ZA - zygomatic arch; SqS - squamous suture; CS - coronal suture; SFS - sphenofrontal suture; SSqS - spheno-squamous suture.

Примечание: TB (temporal bone) - височная кость; SB (sphenoid bone) - клиновидная кость; FB (frontal bone) - лобная кость; ZA (zygomatic arch) - скуловая дуга; SqS (squamous suture) - чешуйчатый шов; CS (coronal suture) - венечный шов; SFS (sphenofrontal suture) - клиновиднолобный шов; SSqS (sphenosquamous suture) - клиновидно-чешуйчатый шов. 
A

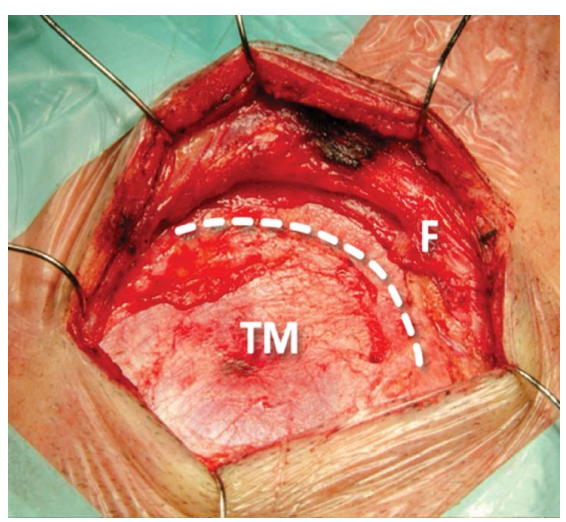

$\mathrm{D}$

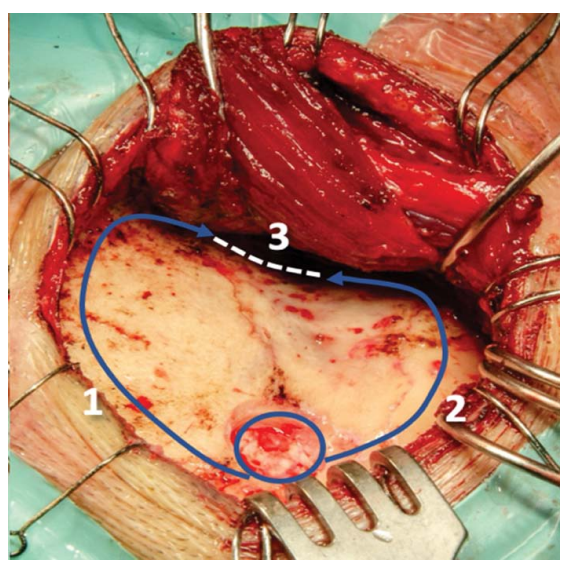

B

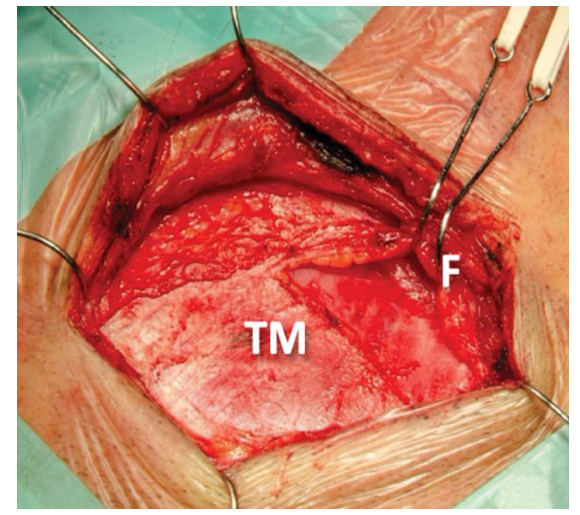

E

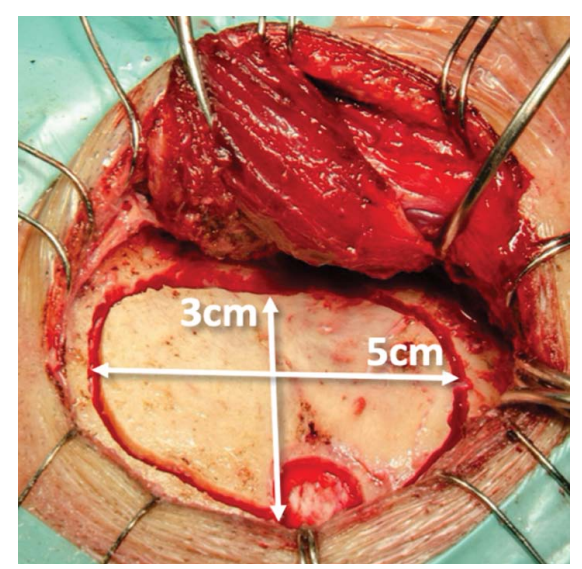

C

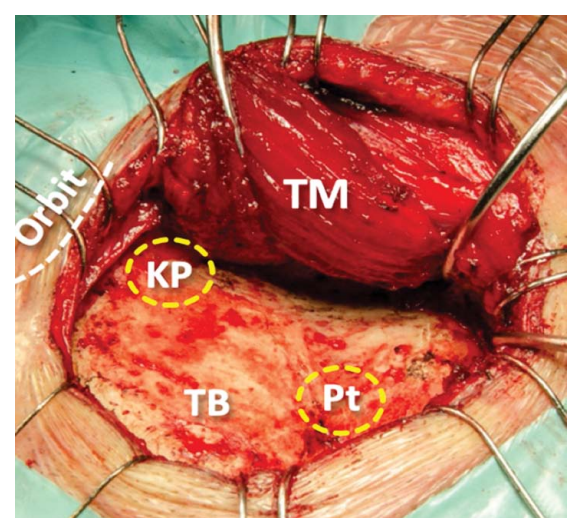

$\mathrm{F}$

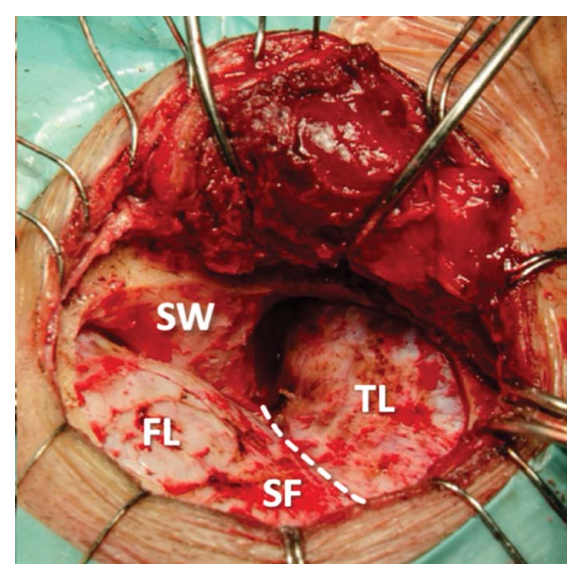

FIG. 5. Intraoperative image of a minipterional craniotomy.

A. Intraoperative image of dissection of interaponeurotic fatty tissue along the border with the temporalis muscle to prevent damage to the branches of the facial nerve: the aponeurotic skin flap is separated along the border with interaponeurotic fatty tissue.

B. Intraoperative image of dissection of interaponeurotic fatty tissue along the border with the temporalis muscle to prevent damage to the branches of the facial nerve: The aponeurotic skin flap is separated along the border between the interaponeurotic fatty tissue and the temporalis muscle, the facial nerve is intact, and the temporalis muscle can be safely dissected downward without the risk of damaging the branches of the facial nerve that remain in the adipose tissue.

C. Intraoperative view of the temporalis muscle dissection: The temporalis muscle is widely dissected from top to bottom, the upper orbital margin and pterion are exposed.

D. Intraoperative image of a minipterional craniotomy: a burr hole is made in the projection of the Sylvian fissure, the upper edge of which is the outer edge of the minipterional craniotomy:

(1) the first stage of the craniotomy is performed in an arcuate manner from the burr hole along the superior temporal line to the large wing of the sphenoid bone;

(2) the second stage of the craniotomy is performed in an arcuate manner from the milling hole to the large wing of the sphenoid bone;

(3) resection of the outer plate of the greater wing.

E. A minipterional craniotomy with bone graft $3 \times 5 \mathrm{~cm}$ was performed.

F. A minipterional craniotomy was performed, the bone flap removed: the dura mater is visible, covering the frontal and temporal lobes of the brain, the course of the Sylvian fissure is traced, the lesser wing of the sphenoid bone is visualized.

РИС. 5. Интраоперационное изображение выполнения мини-птериональной краниотомии.

А. Интраоперационное изображение диссекции жирового комка по границе с височной мышцей для предотвращения повреждения веток лицевого нерва: кожно-апоневротический лоскут отделен по границе с жировым комком.

В. Интраоперационное изображение диссекции жирового комка по границе с височной мышцей для предотвращения повреждения веток лицевого нерва: кожно-апоневротический лоскут отделен по границе между жировым комком и височной мышцей, лицевой нерв цел, височную мышцу можно безопасно рассекать книзу без риска повреждения веток лицевого нерва, которые остаются в жировой ткани.

С. Интраоперационное изображение диссекции височной мышцы: височная мышца широко рассечена книзу, обнажен верхний глазничный край и птерион.

D. Интраоперационное изображение выполнения мини-птериональной краниотомии: выполнено фрезевое отверстие в проекции сильвиевой борозды, верхним краем которого является наружный край мини-птериональной краниотомии: 
(1) первый этап краниотомии выполняется дугообразно от фрезевого отверстия вдоль верхней височной линии к большому крылу клиновидной кости;

(2) второй этап краниотомии выполняется дугообразно от фрезевого отверстия к большому крылу клиновидной кости;

(3) резекция наружной пластинки большого крыла клиновидной кости режущим бором.

Е. Интраоперационное изображение выполнения мини-птериональной краниотомии: выполнена мини-птериональная краниотомия с костным лоскутом $3 \times 5 \mathrm{~cm}$.

F. Интраоперационное изображение выполнения мини-птериональной краниотомии: выполнена мини-птериональная краниотомия, костный лоскут убран. Видна твердая мозговая оболочка, покрывающая лобную и височную доли головного мозга, прослеживается ход сильвиевой борозды, визуализируется малое крыло клиновидной кости.

Note: $\mathrm{F}$ - interaponeurotic fatty tissue; FL - frontal lobe; KP - key point; Pt - pterion; SF - Sylvian fissure; SW - sphenoid wing; TB - temporal bone; $\mathrm{TL}$ - temporal lobe; TM - temporal muscle.

Примечание: F (fat) - межапоневротическая жировая клетчатки; FL (frontal lobe) - лобная доля; KP (key point) - ключевая точка; Pt (pterion) птерион; SF (sylvian fissure) - сильвиева (латеральная) борозда; SW (sphenoid wing) - крыло клиновидной кости; TB (temporal bone) - височная кость; TL (temporal lobe) - височная доля; TM (temporal muscle) - височная мышца.

A

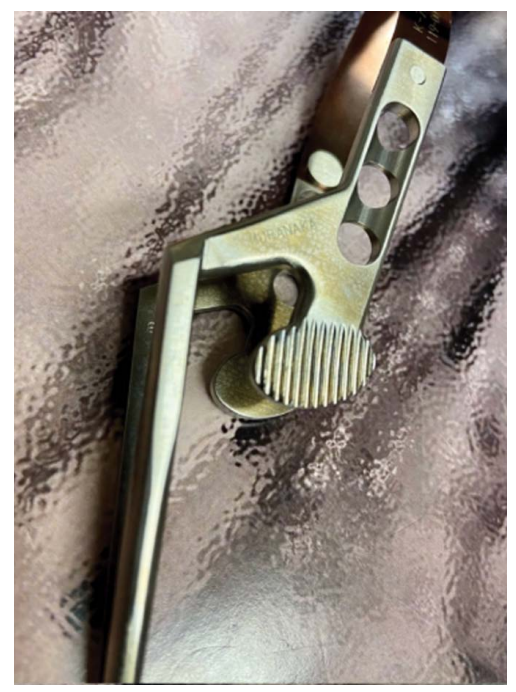

$\mathrm{C}$

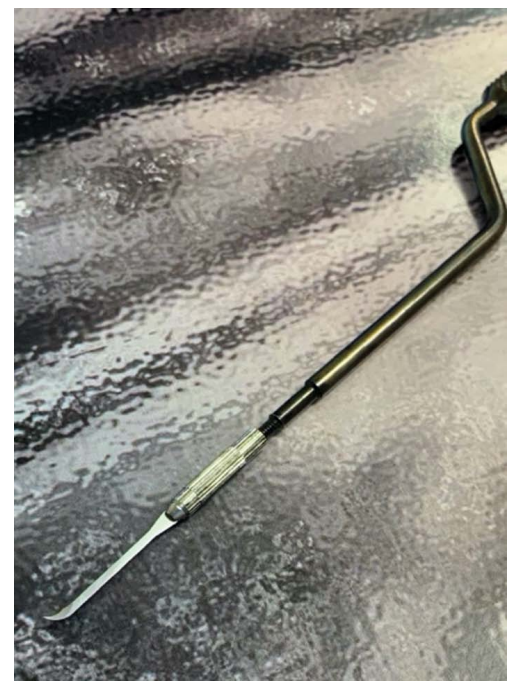

B

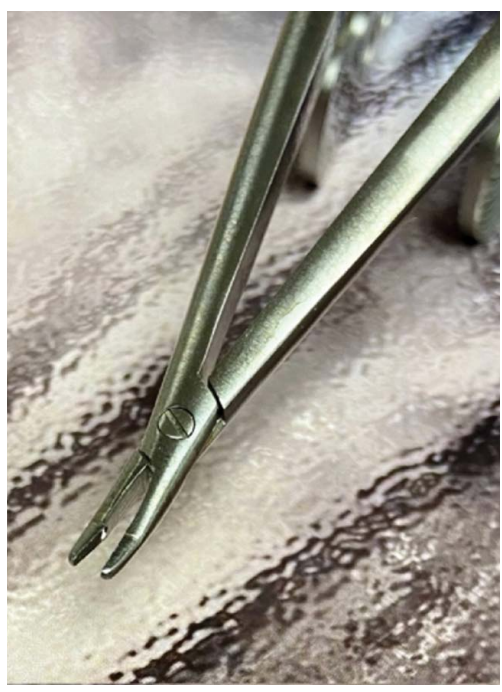

$\mathrm{D}$

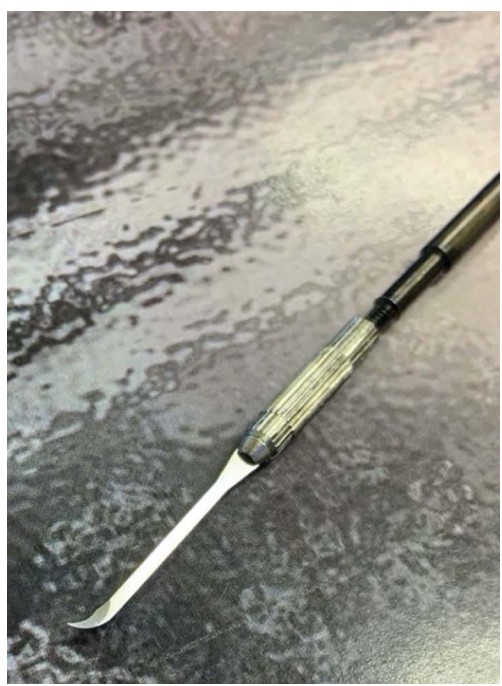

FIG. 6. Microsurgical instruments for extradural anterior clinoidectomy.

A. Bone clippers used for extradural clinoidectomy (Muranaka, Japan) (a general view of the instrument with an original bayonet design that facilitates its use).

B. Bone clippers used for extradural clinoidectomy (Muranaka, Japan) (view of the tool tip.

C. Crescent microdissector for transection of ACP ligaments (Feather, Japan) (general view of a tool with a bayonet grip).

D. Crescent microdissector for transection of ACP ligaments (Feather, Japan) (view of a sickle-shaped blade)

РИС. 6. Микрохирургические инструменты, используемые для выполнения экстрадуральной передней клиноидэктомии. А. Костные кусачки, используемые для экстрадуральной клиноидэктомии (Muranaka, Japan) (общий вид инструмента с оригинальной байонетной конструкцией, улучшающей удобство использования). 
В. Костные кусачки, используемые для экстрадуральной клиноидэктомии (Muranaka, Japan) (вид кончика инструмента). C. Серповидный микродиссектор для пересечения связок ПНО (Feather, Japan) (общий вид инструмента с байонетной ручкой).

D. Серповидный микродиссектор для пересечения связок ПНО (Feather, Japan) (вид лезвия серповидной формы).

Note: ACP - anterior clinoid process.

Примечание: АCP (anterior clinoid process) - передний наклоненный отросток (ПНО).

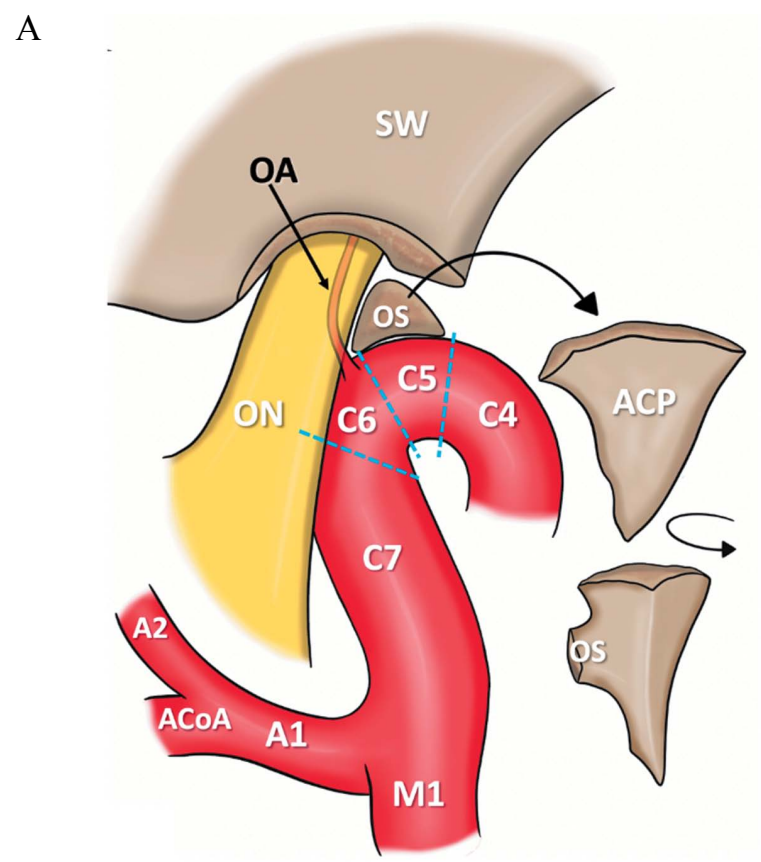

B

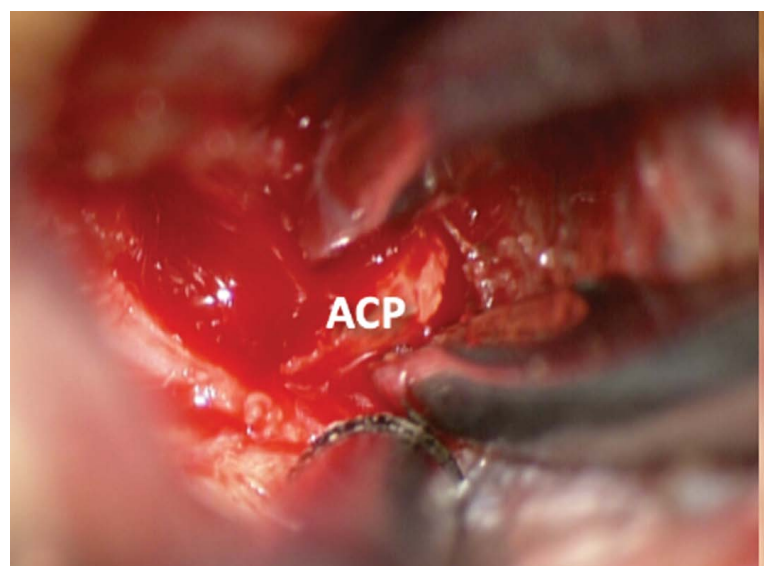

C

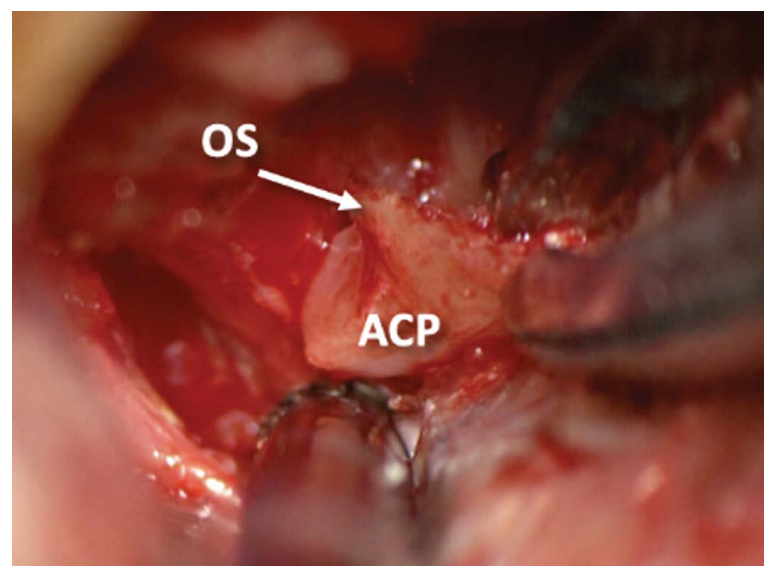

FIG. 7. Extradural anterior clinoidectomy.

A. Schematic representation of the stages of extradural anterior clinoidectomy.

B. Microsurgical stages of extradural anterior clinoidectomy (bone stage of ACP mobilization).

C. Microsurgical stages of extradural anterior clinoidectomy (removal of ACP).

РИС. 7. Экстрадуральная передняя клиноидэктомия.

А. Схематическое изображение этапов выполнения экстрадуральной передней клиноидэктомии.

В. Микрохирургический этап выполнения экстрадуральной передней клиноидэктомии (костный этап мобилизации ПНО).

С. Микрохирургический этап выполнения экстрадуральной передней клиноидэктомии (удаление ПНО).

Note: $\mathrm{A} 1$ - $\mathrm{A} 1$ segment of anterior cerebral artery (ACA); $\mathrm{A} 2$ - A2 segment of $\mathrm{ACA} ; \mathrm{ACOA}$ (anterior communicating artery); $\mathrm{ACP}$ - anterior clinoid process; ICA - internal carotid artery: C4 - cavernous segment, C5 - clinoid segment, C6 - ophthalmic segment, C7 - communicating segment; M1 - M1 segment of middle meningeal artery; OA - ophthalmic artery; ON - optic nerve; OS - optic strut; SW - sphenoid wing.

Примечание: A1 - А1 сегмент передней мозговой артерии; A2 - A2 сегмент передней мозговой артерии; ACoA (anterior communicans artery) передняя соединительная артерия; АСР (anterior clinoid process) - передний наклоненный отросток (ПНО); ICA (internal carotid artery) - внyтренняя сонная артерия: С4 - пещеристый сегмент, С5 - клиноидный сегмент, С6 - офтальмический сегмент, С7 - коммуникативный сегмент; M1 - M1 сегмент средней мозговой артерии; OA (ophthalmic artery) - офтальмическая артерия; ON (optic nerve) - зрительный нерв; OS (optic strut) - зрительная перегородка; SW (sphenoid wing) - крыло клиновидной кости. 
Venous bleeding at this point is stopped with fibrin glue and irrigation.

\section{Dura mater incision}

The dura mater is dissected in a Y-shape. The Y-shaped section of the dura mater is supplemented with a linear one up to the optic nerve. Then the carotid optic cistern is opened microsurgically, the falciform ligament and the distal dural ring are dissected to ensure mobilization of the supraclinoid part of the internal carotid artery and the optic nerve, and the aneurysm, especially its neck, is adequately exposed. When dissecting the distal dural ring of the dura mater, special attention should be paid to the verification of the ophthalmic artery. In unruptured aneurysms, the opening of the optic carotid cistern and drainage of the cerebrospinal fluid cause enough brain relaxation to manipulate ICA aneurysms located in the paraclinoid region, which is necessary to proceed safely with the intradural stage of the operation.

\section{Intradural stage of the operation}

The extradural stage provides a direct approach to the paraclinoid region and guarantees proximal control at all subsequent stages. An arachnoid dissection is then performed at the neck of the aneurysm to expose it sufficiently (Fig. 8A).

A

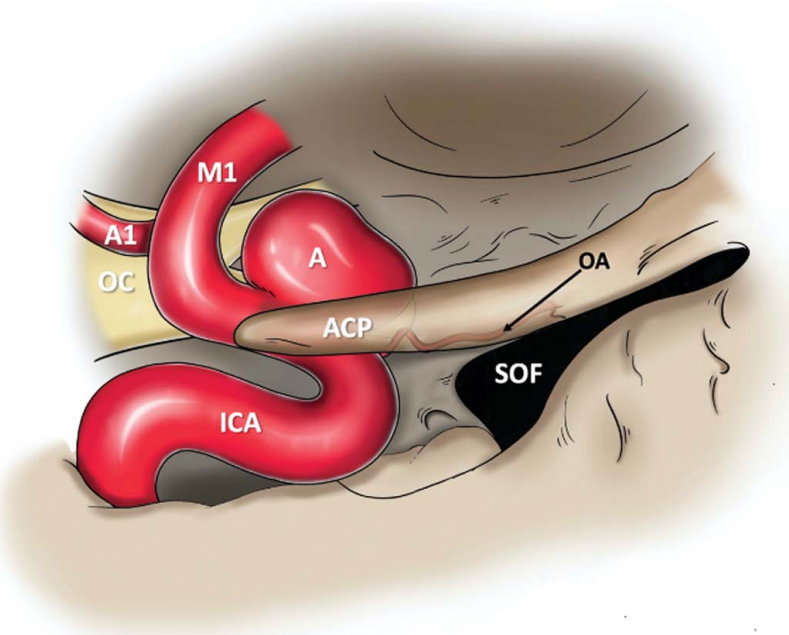

After the neck of the aneurysm has been identified, the clipping of the aneurysm is performed. At this stage, special attention should be paid to the preservation of blood flow in the ophthalmic artery, and to avoid clipping it (Fig. 8B, 9, 10).

\section{Closing the surgical wound}

The dura mater is hermetically sealed, and small defects in the dura mater are closed with the temporal fascia and fibrin glue. This is especially true for the zone of the optic strut and the dissected distal dural ring, and falciform ligament. Since hermetic suturing is not possible, the defect is tamponed with autologous tissue to prevent postoperative CSF leak. The bone flap is fixed with two craniofixes or bone sutures.

The wound is sutured in layers, and the skin with an intradermal cosmetic suture (Fig. 11).

\section{INDICATIONS}

This research paper describes the use of minipterional approach with extradural resection of the anterior clinoid process illustrated with the surgical clipping of carotid-ophthalmic aneurysms. However, the range of indications for this technique is quite wide, with the main ones being other aneurysms of the paraclinoid internal carotid artery that cannot be 'turned off' endovascularly; small

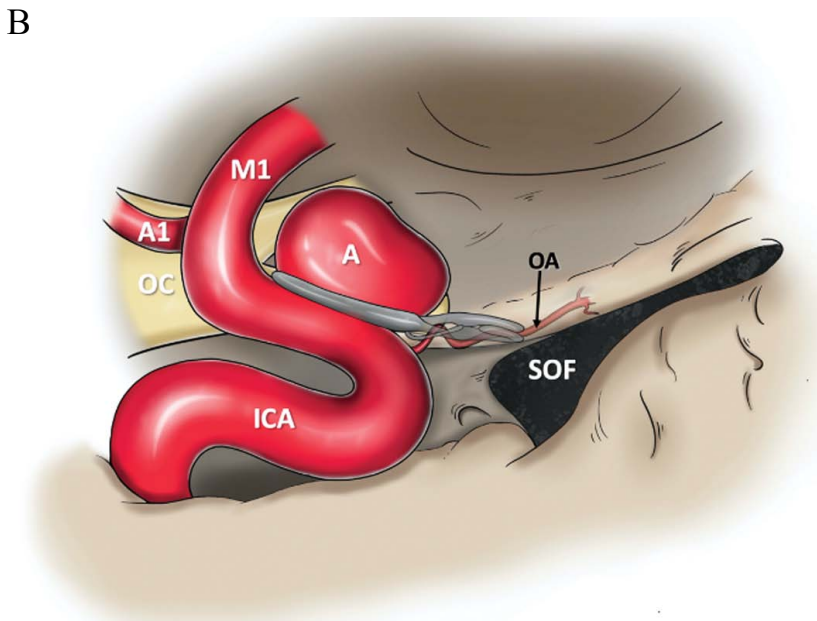

FIG. 8. Schematic representation of the clipping of an aneurysm of the ophthalmic segment of the internal carotid artery.

A. Aneurysm of the ophthalmic segment of the ICA with a wide neck covered by the anterior clinoid process.

B. Clipping of the aneurysm of the ophthalmic segment of the ICA (a permanent clip is placed on the aneurysm neck to block the blood flow in the aneurysm, the blood flow in the ophthalmic artery is preserved).

РИС. 8. Схематичное изображение клипирования аневризмы офтальмического сегмента внутренней сонной артерии.

А. Аневризма офтальмического сегмента ВСА с широкой шейкой, прикрытой ПНО.

В. Клипирование аневризмы офтальмического сегмента ВСА (на шейку аневризмы наложен клипс, кровотока в аневризме нет, кровоток в офтальмической артерии сохранен).

Note: $\mathrm{A}$ - aneurysm; $\mathrm{A} 1$ - $\mathrm{A} 1$ segment of anterior cerebral artery (ACA); $\mathrm{ACP}$ - anterior clinoid process; ICA - internal carotid artery; $\mathrm{M} 1$ - M1 segment of middle cerebral artery (MCA); OA - ophthalmic artery; OC - optic chiasm; SOF - superior orbital fissure.

Примечание: A (aneurism) - аневризма; A1 - A1 сегмент передней мозговой артерии; ACP (anterior clinoid process) - передний наклоненный отросток (ПНО); ICA (internal cerebral artery) - внутренняя сонная артерия (ВСA); M1 - М1 сегмент средней мозговой артерии; ОА (орhthalmic artery) - офртальмическая артерия; ОC (optic chiasm) - перекрест зрительных нервов; SOF (superior orbital fissure) - верхняя глазничная щель. 
A

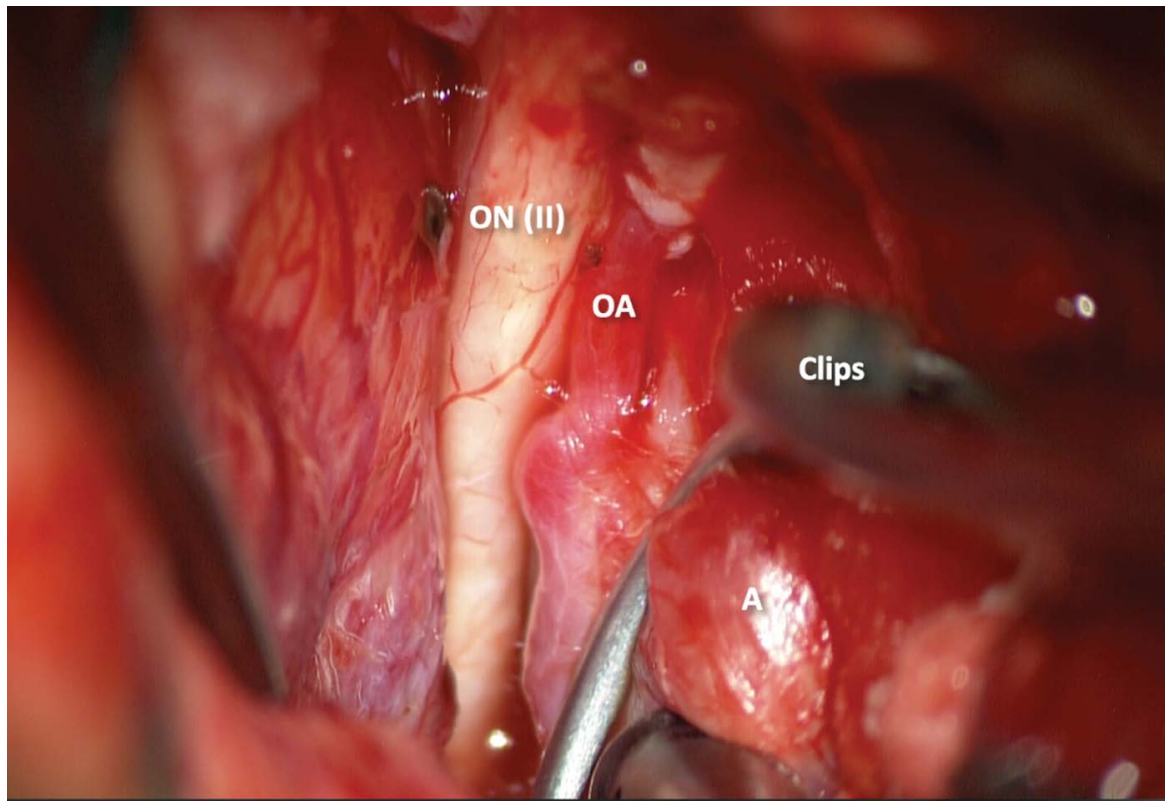

$\mathrm{B}$

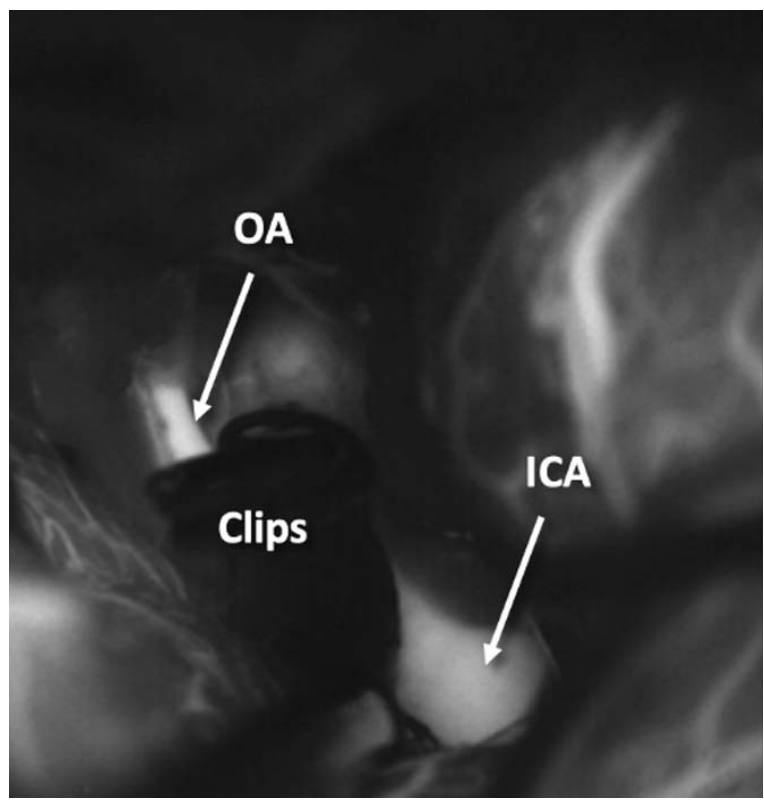

$\mathrm{C}$

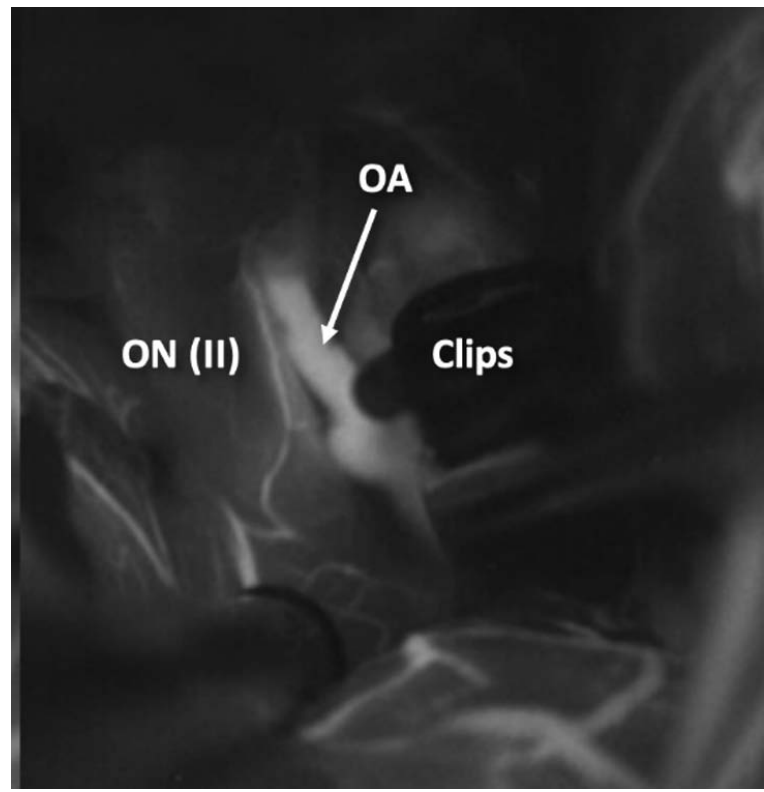

FIG. 9. The clipping of the aneurysm of the ophthalmic segment of the internal carotid artery.

A. Microsurgical image of clipping of the aneurysm of the ophthalmic segment of the ICA (a permanent clip is placed on the aneurysm neck to obstruct the blood flow in the aneurysm, the blood flow in the ophthalmic artery is preserved).

B. ICG fluorescence imaging of the clipped aneurysm of the ICA ophthalmic segment, proximal control (a permanent clip is placed on the neck of the aneurysm, the dome of the aneurysm is not filled with a contrast agent, the blood flow in the ICA is preserved). C. ICG fluorescence imaging of the clipped aneurysm of the ICA ophthalmic segment, distal control (a permanent clip is placed on the neck of the aneurysm, the dome of the aneurysm is not filled with a contrast agent, the blood flow in the ophthalmic artery is preserved).

РИС. 9. Клипирование аневризмы офтальмического сегмента внутренней сонной артерии.

А. Микрохирургический этап клипирования аневризмы офтальмического сегмента ВСА (на шейку аневризмы наложен постоянный клипс, кровотока в аневризме нет, кровоток в офтальмической артерии сохранен).

B. ICG-флуоресцентная визуализация клипирования аневризмы офтальмического сегмента ВCA (на шейку аневризмы наложен постоянный клипс, купол аневризмы контрастным веществом не заполняется, кровоток в ВСА сохранен).

C. ICG-флуоресцентная визуализация клипирования аневризмы офтальмического сегмента ВCA (на шейку аневризмы наложен постоянный клипс, купол аневризмы контрастным веществом не заполняется, кровоток в офтальмической артерии сохранен).

Note: A - aneurysm; Clips - clips are placed on the neck of the aneurysm; OA - ophthalmic artery; ICA - internal carotid artery; ON - optic nerve.

Примечание: A (aneurism) - аневризма; Clips - наложенный на шейку аневризмы клипс; OA (ophthalmic artery) - офттальмическая артерия; ICA (internal carotid artery) - внутренняя сонная артерия; ON (optic nerve) - зрительный нерв. 
A

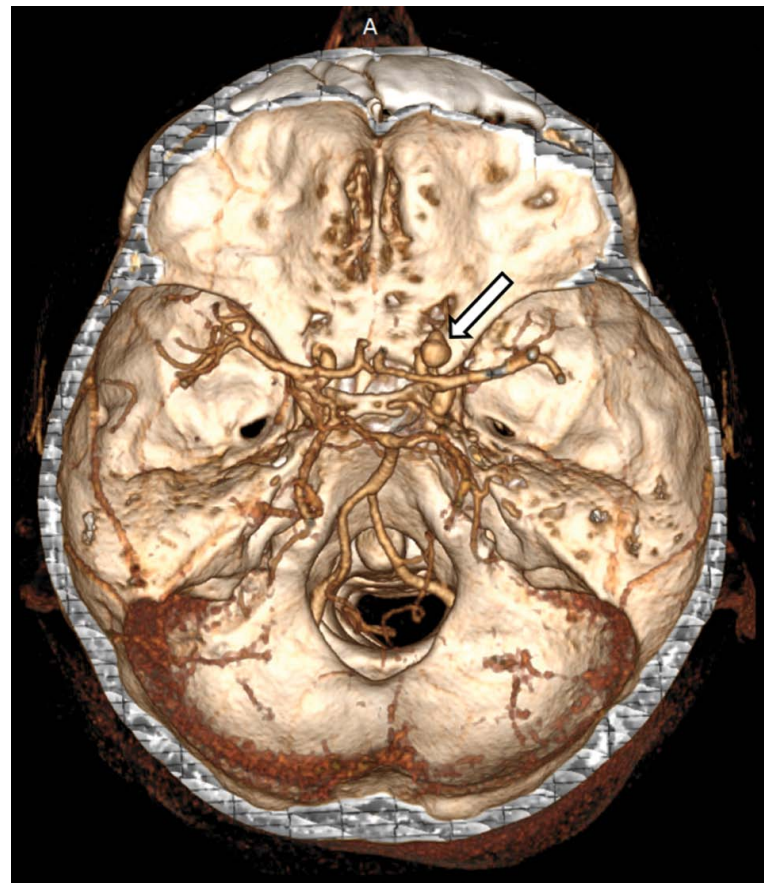

B

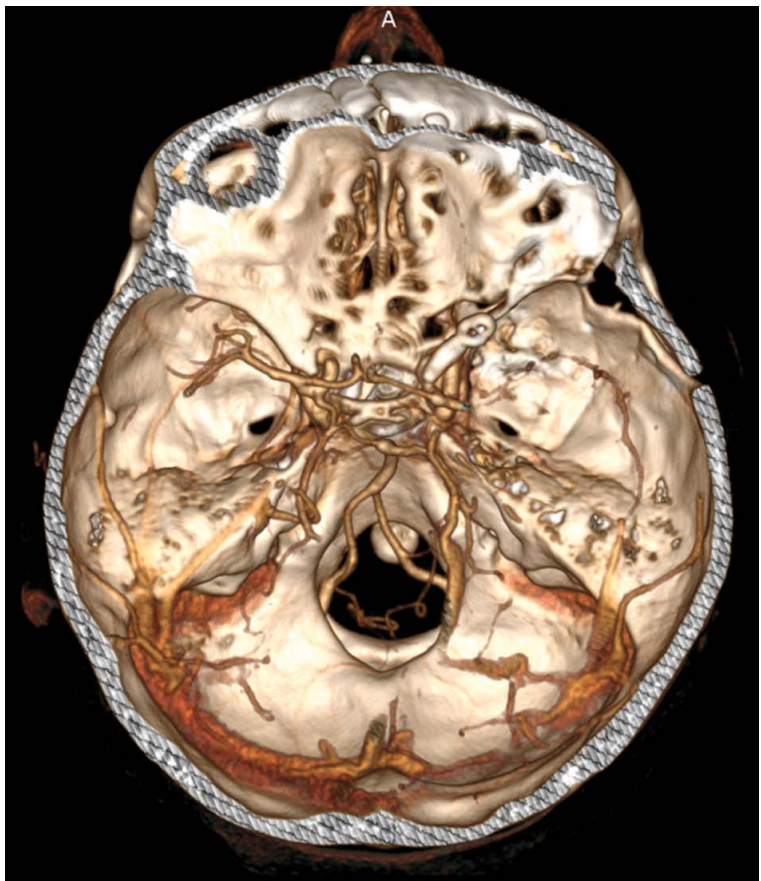

FIG. 10. Results of computed tomography angiography of a patient with an aneurysm of the ophthalmic segment of the internal carotid artery before and after the surgical treatment.

A. preoperative angiogram, a visualized aneurysm of the ICA ophthalmic segment (arrow).

B. postoperative angiogram, the clip is placed on the neck of the aneurysm, the dome of the aneurysm is not filled with a contrast agent.

РИС. 10. Результаты компьютерной томографической ангиографии пациента с аневризмой офтальмического сегмента внутренней сонной артерии до и после оперативного вмешательства.

А. Результаты КТ-ангиографии до оперативного вмешательства, визуализируется аневризма офтальмического сегмента ВСА (указана стрелкой).

В. Результаты КТ-ангиографии после оперативного вмешательства, визуализируется клипс, наложенный на шейку аневризмы, купол аневризмы контрастным веществом не заполняется.

Note: ICA - internal carotid artery.

Примечание: ICA (internal carotid artery) - внутренняя сонная артерия (BCA).

A

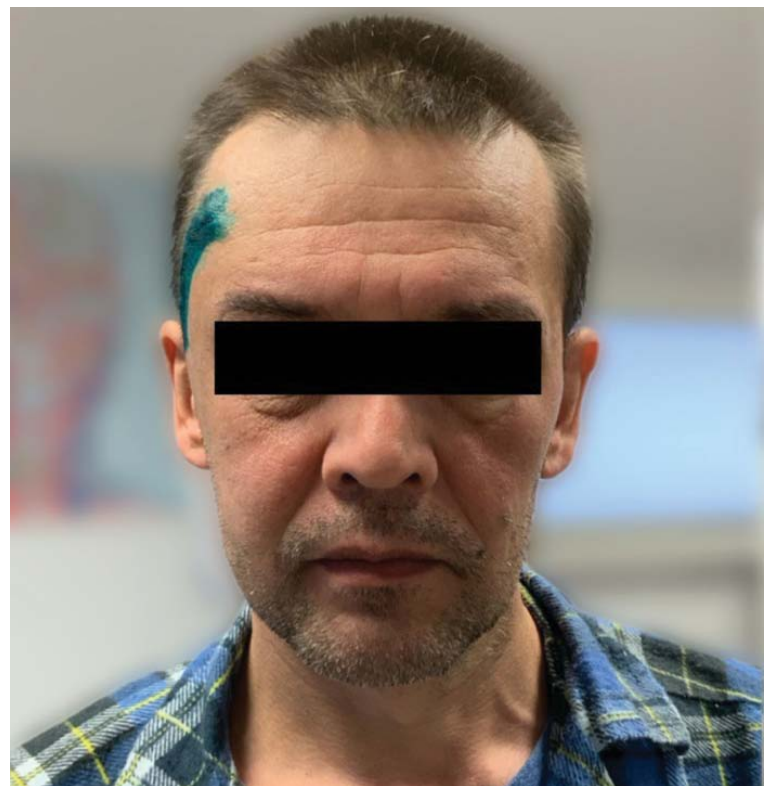

B

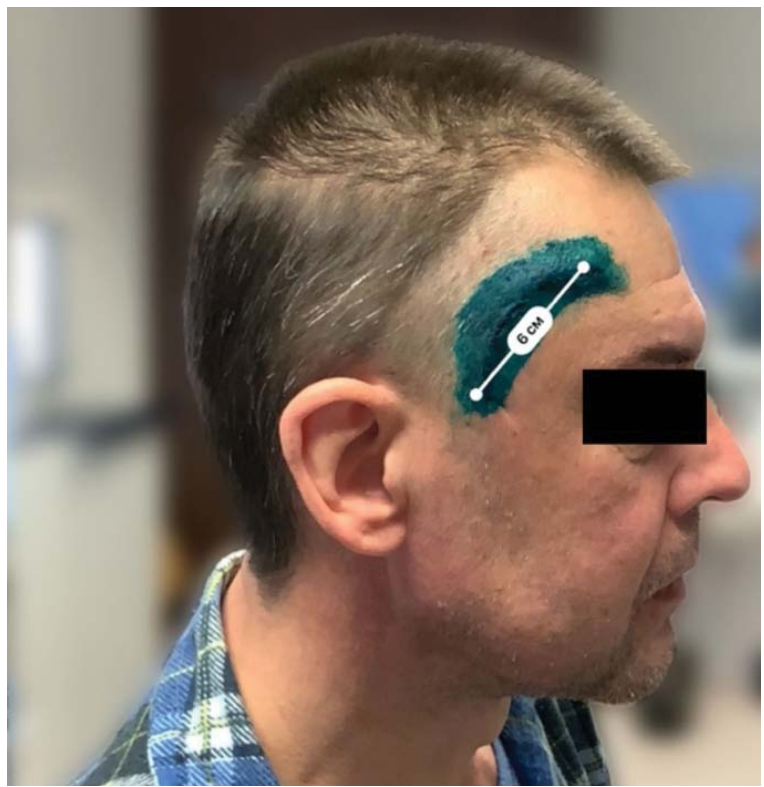

FIG. 11. Postoperative view of the skin wound and good cosmetic effect, no face asymmetry.

A. Frontal view. B. Side view.

РИС. 11. Послеоперационный вид кожной раны и хороший косметический эффект, отсутствие асимметрии лица.

А. Вид спереди. В. Вид сбоку. 
mass lesions of the sella turcica, the areas of the sphenoid bone wings, and the anterior clinoid process; ophthalmic nerves gliomas; necessity for the optic canal decompression, etc.

\section{MAIN ADVANTAGES}

Excellent cosmetic effect (skin incision 5-7 centimeters long behind the hairline, maintaining the integrity of the branches of the facial nerve, craniotomy with a diameter of 3-5 centimeters). Additional resection of bone tissue at the extradural stage provides additional volume for surgical manipulations and optimal angles of attack for this keyhole approach, which determines the absence of direct manipulations with brain tissue during extradural clinoidectomy, and, accordingly, the absence of brain injury.

Early proximal control obtained after ACP resection allows for safe clipping of aneurysms that have a high risk of rupture, and in the case of an intraoperative rupture, a temporary clip can easily be applied to the ICA region, proximal to the aneurysm.

\section{MAIN LIMITATIONS}

The main limitation of the minipterional approach with extradural ACP resection is the possible intraoperative rupture of the aneurysm during rough clinoidectomy. However, the learning curve of the operating neurosurgeon and the use of delicate specialized neurosurgical instrumentation minimizes the possibility of this complication.

The small size of the craniotomy makes it difficult for two neurosurgeons to work simultaneously, which requires relevant surgical training and experience, along with appropriate neurosurgical instruments.

In addition, it is always necessary to be aware of possible bleeding from the cavernous sinus located in the immediate vicinity of the surgical manipulation area, and to have the necessary means and experience to perform a thorough hemostasis.

\section{AUTHORS CONTRIBUTIONS}

Albert A. Sufianov carried out the surgical procedure described in the submitted publication, made a major contribution to the conception and design, and supervised the scientific article writing and editing process; Egor S. Markin, Ivan S. Shelyagin and Rinat A. Sufianov participated in the conception and design of the publication, preparation of materials, writing and editing the text, as well as preparing the illustrations. All authors approved the final version of the article and are ready to take responsibility for all aspects of the submitted publication.

\section{Compliance with ethical standards}

Consent statement. The patient has consented to the submission of this "How I do it" to the Sechenov Medical Journal.

\section{SPECIFIC INFORMATION TO PROVIDE THE PATIENT WITH REGARDING THE SURGERY AND POTENTIAL RISKS}

The information to be given to the patient before the surgical intervention is essentially the same as in the case of microsurgical clipping of aneurysms, but the potential risks are higher due to the nature of the craniotomy performed. The risk of intraoperative aneurysm rupture is increased by extradural clinoidectomy, and the patient should be informed of this before the operation, but the risk is still low, and such complications have not occurred in our practice. The risk of haemorrhagic complications also increases with the surgical procedures described and may be associated with some heavy bleeding from the cavernous sinus, which must also be communicated to the patient before the operation. The small size of the craniotomy can make it difficult to seal the dura mater and lead to early postoperative complications in the form of CSF leakage and infectious inflammatory changes. Nevertheless, if the operating surgeons have enough experience, the risk is insignificant and such cases have not occurred in our series.

\section{CONCLUSION}

The minipterional approach with extradural resection of the ACP is a safe surgical approach, which can exemplify the efficacy of adding some elements of skull base surgery to keyhole approaches. This combined approach contributes to a significant expansion of the range of neurosurgical pathologies which could benefit from this type of craniotomy. However, this technique is more demanding both from the point of view of the manual skills of the surgeon and the instrumental support needed. But with qualified personnel, as well as all the necessary tools, for example, in neurosurgical clinics, as well as in modern neurosurgical departments of multidisciplinary clinical centers, this approach can become a "method of choice" in the treatment of a wide range of neurosurgical pathology.

\section{ВКЛАД АВТОРОВ}

А.А. Суфианов выполнил описываемое в представленной публикации оперативное вмешательство, внес основной вклад в разработку концепции и принял на себя руководство написанием научной статьи и редакцией ее текста. Е.С. Маркин, И.С. Шелягин и Р.А. Суфианов приняли участие в разработке концепции публикации, подготовке материалов, написании и редактировании текста, а также подготовке иллюстраций. Все авторы утвердили окончательную версию статьи и готовы принять на себя ответственность за все аспекты представленной публикации.

\section{Соблюдение этических норм}

Заявление о согласии. Пациент дал согласие на публикацию представленной выше статьи «Как я это делаю» в журнале «Сеченовский вестник». 


\section{REFERENCES / ЛИTEPATYPA}

1 Xin W.Q., Wang W.H., Yin Q., et al. Meta-analysis of pterional versus supraorbital keyhole approach for clipping intracranial aneurysms: direct comparison of approach-related Complications. World Neurosurg. 2020 Mar; 135: e246-e257. https://doi. org/10.1016/j.wneu.2019.11.134. Epub 2019 Nov 29. Erratum in: World Neurosurg. 2020 Jul; 139: 789. PMID: 31790840.

2 Rodriguez-Rubio R., Chae R., Vigo V., et al. Immersive Surgical Anatomy of the Pterional Approach. Cureus. 2019 Jul 23; 11(7): e5216. https://doi.org/10.7759/cureus.5216. PMID: 31555496.

3 Rychen J., Croci D., Roethlisberger M., et al. Keyhole approaches for surgical treatment of intracranial aneurysms: a short review. Neurol Res. 2019 Jan; 41(1): 68-76. https://doi.org/10.1080/0161 6412.2018.1531202. Epub 2018 Oct 12. PMID: 30311865.

4 Rychen J., Croci D., Roethlisberger M., et al. Minimally Invasive Alternative Approaches to Pterional Craniotomy: A Systematic Review of the Literature. World Neurosurg. 2018 May; 113: 163 179. https://doi.org/10.1016/j.wneu.2018.02.016. Epub 2018 Feb 13. PMID: 29452317.

5 Mura J., Perales I., Rabelo N.N., et al. Extradural minipterional approach: Evolving indications of the minipterional craniotomy. Surg Neurol Int. 2020 May 16; 11: 109. https://doi.org/10.25259/ SNI_169_2020. PMID: 32494386.

6 Martínez-Pérez R., Mura J.M. The Extradural Minipterional Approach: "Think Small, Play Wider". World Neurosurg. 2019
May; 125: 534-535. https://doi.org/10.1016/j.wneu.2018.10.240. PMID: 31262431.

7 Martínez-Pérez R., Albonette-Felicio T., Zachariah M.A., et al. Quantitative Anatomic Study of the Minipterional Craniotomy in the Paraclinoid Region: Benefits of Extradural Anterior Clinoidectomy. World Neurosurg. 2020 Mar; 135: e221-e229. https://doi.org/10.1016/j.wneu.2019.11.120. Epub 2019 Nov 28. PMID: 31786378.

8 Alkhalili K.A., Hannallah J.R., Alshyal G.H., et al. The minipterional approach for ruptured and unruptured anterior circulation aneurysms: Our initial experience. Asian J Neurosurg. 2017 JulSep; 12(3): 466-474. https://doi.org/10.4103/1793-5482.180951. PMID: 28761525.

9 Salgado López L., Muñoz Hernández F., Asencio Cortés C., et al. Extradural anterior clinoidectomy in the management of parasellar meningiomas: Analysis of 13 years of experience and literature review. Neurocirugia (Astur). 2018 Sep-Oct; 29(5): 225-232. English, Spanish. https://doi.org/10.1016/j.neucir.2018.04.002. Epub 2018 May 9. PMID: 29753644.

10 Szmuda T., Stoniewski P., Ali S., et al. Extent of anterior clinoidectomy for clipping of carotid-ophthalmic aneurysms predicted on three-dimensional computerised tomography angiography. Neurol Neurochir Pol. 2020; 54(2): 138-149. https://doi.org/10.5603/ PJNNS.a2020.0017. Epub 2020 Feb 26. PMID: 32101325.

\section{INFORMATION ABOUT THE AUTHORS / ИНФОРМАЦИЯ ОБ АВТОРАХ}

Albert A. Sufianov, Dr. of Sci. (Medicine), Professor, Head of Federal Centre of Neurosurgery; Head of the Department of Neurosurgery, Sechenov First Moscow State Medical University (Sechenov University).

ORCID: https://orcid.org/0000-0001-7580-0385

Egor S. Markin, neurosurgeon, Federal Centre of Neurosurgery.

ORCID: 0000-0002-4423-5165

Ivan S. Sheliagin $\bowtie$, neurosurgeon, Federal Centre of Neurosurgery; Postgraduate at the Department of Operative Surgery and Topographic Anatomy, Sechenov First Moscow State Medical University (Sechenov University).

ORCID: https://orcid.org/0000-0002-0877-7442

Rinat A. Sufianov, Assistant Professor, Department of Neurosurgery, Sechenov First Moscow State Medical University (Sechenov University); Postgraduate of the 7th neurosurgical department (glial tumors), Burdenko Neurosurgical Institute.

ORCID: https://orcid.org/0000-0003-4031-0540
Суфианов Альберт Акрамович, д-р мед. наук, професcop, главный врач ФГБУ «Федеральный центр нейрохирургии» Минздрава России; зав. кафедрой нейрохирургии ФГАОУ ВО «Первый МГМУ им. И.М. Сеченова» Минздрава России (Сеченовский Университет). ORCID: https://orcid.org/0000-0001-7580-0385

Маркин Егор Сергеевич, нейрохирург ФГБУ «Федеральный центр нейрохирургии» Минздрава России. ORCID: https://orcid.org/0000-0002-4423-5165

Шелягин Иван Сергеевич ${ }^{\bowtie}$, нейрохирург ФГБУ «Федеральный центр нейрохирургии» Минздрава России; соискатель кафедры оперативной хирургии и топографической анатомии ФГАОУ ВО «Первый МГМУ им. И.М. Сеченова» Минздрава России (Сеченовский Университет). ORCID: https://orcid.org/0000-0002-0877-7442

Суфианов Ринат Альбертович, ассистент кафедры нейрохирургии ФГАОУ ВО «Первый МГМУ им. И.М. Сеченова» Минздрава России (Сеченовский Университет); аспирант 7-го нейрохирургического отделения (глиальные опухоли) ФГАУ «НМИЦ нейрохирургии им. ак. Н.Н. Бурденко» Минздрава России.

ORCID: https://orcid.org/0000-0003-4031-0540

Автор, ответственный за переписку / Corresponding author 